\title{
10
}

\section{Learning Enterprise and Entrepreneurship Through Real Business Projects}

\author{
Lucy Hatt
}

\section{Introduction}

Global and European economic and employment policies increasingly emphasise the importance of enterprise and entrepreneurship. Entrepreneurship is the "key to job creation and growth in modern society" (Nielsen, Klyver, Evald, \& Bager, 2012, p. xv), and entrepreneurial competencies are highly sought after by policy-makers and practitioners (Hofer et al., 2010).

The Finnish 'Tiimiakatemia' which started in 1993 at JAMK University of Applied Sciences in Jyväskylä, Finland (Team Academy Worldwide, n.d.), was developed in response to this demand for more entrepreneurial graduates and the changing nature of the job market. Students on such undergraduate degree programmes learn in coached teams by starting and running real businesses.

Case studies: Lucy Hatt and Lauren Davies

L. Hatt $(\bowtie)$

Newcastle University, Newcastle upon Tyne, UK e-mail: lucy.hatt@newcastle.ac.uk 
This chapter introduces entrepreneurship in education and offers a critique of the experiential real world nature of the Team Academy approach, suggesting a complementary conceptual grounding using the threshold concepts framework (Meyer \& Land, 2003, 2005) to identify what is distinctive about entrepreneurship to enable curricular development and the integration of entrepreneurship with diverse academic subjects beyond business.

The chapter includes four case studies from two UK universities using a Team Academy informed approach: Northumbria University and the University of the West of England.

\section{Entrepreneurship and Entrepreneurship Education}

Entrepreneurship is important as it is a significant factor in driving economic growth (Entrepreneurship Policy Framework and Implementation Guidance, 2012). Enterprise and entrepreneurship education have been identified as potential enablers of positive social, economic and political change, increasing the likelihood of successful graduate employment across all subject areas, and positively contributing to the likelihood of graduates leading "rewarding and self-determined" professional lives (Entrepreneurship Policy Framework and Implementation Guidance, 2012; Matlay \& Carey, 2007; QAA, 2018). Higher education is generally regarded as an appropriate place for the development of entrepreneurship (QAA, 2012).

According to the QAA (2018, p. 7), enterprise is "the generation and application of ideas, which are set within practical situations during a project or undertaking". They define entrepreneurship as "the application of enterprise behaviours, attributes and competencies into the creation of cultural, social or economic value". There is, however, a general lack of consensus regarding what entrepreneurship education in higher education really means (Pittaway \& Cope, 2007), what needs to be learnt, whether it can be learnt, where it is best learnt, how to learn it and how to measure if it has been learnt. There remain unanswered questions 
concerning how (and if) the higher education sector can contribute to entrepreneurship (Davey, Hannon, \& Penaluna, 2016). There is no stable canon of knowledge that represents entrepreneurship and no established methodology for entrepreneurship education (Michels, Beresford, Beresford, \& Handley, 2018). A general lack of research-grounded discussion on the quality of entrepreneurship education initiatives has been highlighted (Béchard \& Grégoire, 2007), particularly in relation to what makes pedagogical innovations effective. There is a concern that the emergence and growth in entrepreneurship education has been faster than educators' understanding of what should be taught, and how outcomes might be assessed (Neck \& Corbett, 2018).

Providing academic content to potential entrepreneurs offers some benefits, but merely treating entrepreneurship as just another subject is not likely to be effective. According to the Economist Intelligence Unit (Helping entrepreneurs flourish: Rethinking the drivers of entrepreneurship, 2014), entrepreneurs have clear opinions regarding what would make more effective entrepreneurship education. They hold that education needs to go beyond imparting a specific body of knowledge, believing this approach to be largely obsolete given the growing accessibility of data. Education needs to be more experience driven and personalised, where students can learn how to apply information together with skills of creativity and problem solving. Educators need to create learning environments where risk taking is encouraged so students realise that failure is a normal part of development. Networking is also of primary importance, learning the skills necessary to network successfully and the role of networking in enabling better contact with the professional world both for employment and for mentoring purposes.

Existing approaches to entrepreneurship education can be broadly grouped into three (Hannon, 2005; Heinonen \& Hytti, 2010; O'Connor, 2013) or, with the addition of 'embedded', four (Gibb, 2002; Lackéus, 2015a; Morselli, 2019; Pittaway \& Edwards, 2012):

1. 'Teaching about': a theoretical approach to gain an understanding of the phenomenon of entrepreneurship. 'About' approaches are theoretical and guided by content. 
2. 'Teaching for': a vocational approach to learn the skills, knowledge and attitude needed to become an entrepreneur. 'For' approaches are orientated to occupation.

3. 'Teaching through': an experiential approach to develop an understanding of entrepreneurship through experiencing entrepreneurial processes, the aim being to go through a real entrepreneurial learning process in 'safe' conditions.

4. In embedded approaches entrepreneurship is delivered within other non-business subjects, the aim being to give learners entrepreneurial experience and awareness relevant to their field of study (Pittaway \& Edwards, 2012).

Whilst 'teaching for' and 'teaching through' have gained in popularity, some regard 'teaching about' as indispensable because, they argue, only by understanding theoretical frameworks can students adapt and flourish in an uncertain future (Fiet, 2001). Others argue that 'for' and 'about' approaches are the most relevant to students wishing to become entrepreneurs, whilst the 'through' and 'embedded' approaches are useful to any student (Lackéus, 2015a). There is a tension between what is easy to deliver in the existing educational context and what is most effective.

Despite continuing debate about whether entrepreneurship can be taught and, if so, how best to teach it and whether university is the right place to learn it, the prevailing neo-liberal ideology has led to a huge increase in the provision of entrepreneurship education in higher education. This fragmented and disparate educational landscape has resulted from differing assumptions about the purpose of entrepreneurship education at university.

The three main themes evident when identifying the purpose and impact of entrepreneurship education, namely increasing the number and success of new ventures; enhancing the employability of graduates and increasing their value in the job market; and preparing students for an uncertain future, are equally important but difficult to measure and connect directly with any specific educational intervention. This lack of clarity concerning an overarching purpose is also evident in the sector as a whole and not just in entrepreneurship. As Rothblatt (2006) notes, there is a general lack of clarity around what a university is, or what one 
is for. Moreover, disparate purposes of entrepreneurship education inhibit effective curricula development. A more conceptual approach is called for. This chapter proposes that the objective of entrepreneurship education is to further knowledge and understanding of entrepreneurship and to enable students to understand how an entrepreneur thinks and practises in the world.

\section{Team Academy}

The Team Academy approach undoubtedly produces some very desirable outcomes. Graduate employment levels and number of student start-ups are claimed to be significantly higher than those of other more traditional programmes (Tosey, Dhaliwal, \& Hassinen, 2015). Increased selfawareness is the most commonly reported and most highly valued participant outcome (Ruuska \& Krawczyk, 2013), and visitors are typically impressed by the confidence, capability and energy of team entrepreneurs (students), and their ability to take initiative and responsibility (Tosey et al., 2015). Students emerge with excellent soft-skills and a highly developed network of potential customers, employers, mentors and investors (Davey, 2016).

The Team Academy approach represents a very new way of structuring and delivering an undergraduate programme, and it has little defined knowledge content. In the original Finnish version of the approach, nothing is taught didactically and there is no set curriculum. Students have to acclimatise to a learning environment where there is minimal direction and instruction regarding what to learn or how to learn it. The Team Academy approach deliberately positions itself as radically different to traditional forms of higher education typically organised by academic discipline and shifts the focus from teaching to learning, but not learning according to what is determined by the educator. Team Academy does not give its students grounding in the typical range of business disciplines and justifies this by arguing that the students' own reading is led by the business needs and development of the individual. It is also based on a premise that specialist expertise, when needed, can be sourced externally. 
Team Academy is described as a "radical form of socio-constructivism" or "radical constructivism", it is based on a "constructive-humanistic learning concept" (see Akatemia-working to learn, 2019; Davey, 2018; Halttunen, 2006; Leinonen, Partanen, \& Palviainen, 2004; Lizartza, 2012). It is representative of programmes where constructivist views have become ideologically and epistemologically opposed to the presentation and explanation of knowledge (Kirschner, Sweller, \& Clark, 2006).

Teams of students create and operate real business projects supported by coaches in a conscious and deliberate contrast to traditional business programmes that might offer a form of experiential learning through the use of simulations. The students own their businesses outright and the universities have no stake in them. This level of authentic investment in the success or failure of their business projects increases the students' levels of psychological and emotional engagement in their enterprises (Tosey et al., 2015). Students are organised to work in teams and tasked with making money, pooling their experience to become more personally effective and to develop effective team working skills.

The experience is centred on regular sessions with a coach, typically called training or coaching sessions or action learning sets once or twice a week, where the coach encourages dialogue to facilitate peer learning and knowledge creation. In these sessions, students sit with their coach in a circle. They discuss their business projects, what they have learned, report on finances and plan. The coach may be an academic member of staff or an external business-person with relevant business start-up experience, depending on the institution.

Northumbria University at Newcastle and the University of the West of England were the first two UK universities to introduce a Team Academy style programme in 2013. Some six years later, the programmes retain some but not all of the original Team Academy features. Re-applying the Team Academy approach wholesale in other countries has many challenges, indeed Tosey et al. (2015) argue that the Team Academy model worked integrally as a coherent whole and queried whether it could be transferred successfully outside the host nation with any modifications at all, however rational or necessary they appeared. This view is not shared by all and Davey's case study (2016, p. 14) calls the Team Academy model 
"highly transferrable" owing to "its well-structured and documented approach, which can be adapted to the needs of the host institution".

For example, in the Northumbria version of Team Academy, students cannot hire and fire each other as they all pay fees, neither can progression on the programme be dependent on any other criteria than satisfactory performance in summative assessments. The university cannot charge students for 'office rental', and there are no equivalent preferential tax arrangements for business co-operatives. The institutional requirements regarding quality assurance dictate a modular format for the degree, making non-module specific sessions challenging to timetable and workload, and this impacts on the design of assignments. As the programme has developed at Northumbria University, taught knowledge content has been introduced, although there is considerably less content than on other mainstream Business Management programmes. The description of the course given by a 2019 graduate sums up the student experience.

We did not generally have lectures or seminars. On the course we had a variety of business and academic coaches with very different backgrounds stretching from Venture Capitalism, Serial and Portfolio Entrepreneurship to Careers and the Psychology of the Entrepreneurial Mind-set. Although this system was hard to adopt initially in first year, I honestly think it was for the best. We had coaches with real experience in business that could provide us with contacts, help grow our business networks and teach us how to get through business struggles, all of which were extremely important for our own personal development as business students and potential entrepreneurs. I feel we are extremely well prepared for the workplace due to the way that the course was designed. We had coaching sessions twice a week where we could choose what to learn and we had to take ownership of our own learning. I must admit this was hard at first when we didn't have businesses, but as soon as we started doing real business activity, each and every one of us came to a coaching session passionate about teaching something that we had learnt and eager to listen to see if we could apply others' lessons to our own business projects. It was like a positive multiplier effect. Our assignments' objectives were to integrate the academic literature of business with the practical application of our businesses in context. This was a great way to make our assignments very interesting and also a good 
way to force us to do the parts of business that most people tend not to enjoy such as accounting and planning, etc. I also loved how the feedback received was always based on our business activity as well as the assignment criteria.

The current programme design addresses aspects of 'learning through' and 'learning for' entrepreneurship, but important aspects of 'learning about' can be further strengthened through application of the threshold concept framework. Candidate threshold concepts in entrepreneurship are proposed here as particular types of knowledge that are central to entrepreneurship that will enable educators to teach entrepreneurship better and to improve the learning experience of students (Barradell \& Kennedy-Jones, 2015).

\section{Candidate Threshold Concepts in Entrepreneurship}

The threshold concept framework posits that in any academic discipline there are concepts that have a particularly transformative effect on student learning. Termed threshold concepts, they represent a transformed way of understanding something, without which the learner cannot progress (Meyer \& Land, 2005). In transforming the learner, threshold concepts change the learner's perceptions, subjectivity and worldview. There is a repositioning of the self (Meyer \& Land, 2005) where the learners' understanding of the nature of their own existence and their conception of reality adjusts; an ontological as well as a conceptual shift. This can often be uncomfortable and is therefore sometimes resisted. Mastery of a threshold concept simultaneously changes an individual's idea of what they know and who they are (Cousin, 2009). Such conceptual understanding is likely to be irreversible and is unlikely to be forgotten or unlearned. Threshold concepts are also characterised by their integrative nature in that they expose how other things can be related to each other.

Defining the threshold concepts in any subject discipline is likely to inform the development of the curriculum in order that it might be optimised. Threshold concepts are concepts that bind a subject together, being fundamental to ways of thinking and practising in that discipline 
(Meyer \& Land, 2003, 2005). The concepts that are critical to thinking as an entrepreneur, and consequently to entrepreneurship, may be termed entrepreneurship threshold concepts (Meyer \& Land, 2003, 2005). Using the threshold concept framework (Meyer \& Land, 2003) to define entrepreneurship presents an important opportunity in terms of both the credibility of the subject area and the design and delivery of enterprise and entrepreneurship curricula in higher education. The use of the term 'candidate threshold concept' (CTC) started to appear from 2008 (Osmond, Turner, \& Land, 2008; Shanahan, Foster, \& Meyer, 2008; Zander et al., 2008) and has been used here to communicate a sense of fluidity and openness to the potential evolution of these concepts in entrepreneurship. CTCs in entrepreneurship are being offered as starting points for discussion, selection and further consideration, not as absolute fixed definitions.

\section{The Promise of Threshold Concepts in Entrepreneurship}

Identifying threshold concepts in entrepreneurship could be useful for entrepreneurship educators in a number of respects: to avoid an overstuffed curriculum, to unblock student learning and facilitate curriculum development and to demarcate the discipline.

Identifying some concepts as 'threshold' offers a way of differentiating between core learning goals which enable the learner to see things in a different way and other learning goals which, though important, do not have the same significantly enabling and transformative effect. This allows the educator to focus on the conceptual understandings that enable a fuller understanding of the subject, and foster integration of knowledge, avoiding an over-crowded curriculum. The burgeoning interest in entrepreneurship education, as perhaps typical of any subject seeking to establish itself as an academic discipline, has led to a proliferation of learning outcomes and competencies that risk overwhelming an entrepreneurship educator wishing to address the subject comprehensively. That said, there are methodological challenges in distinguishing between 'key', 'core' and 'threshold' concepts (Barradell, 2013). 
Failure to understand, view or interpret a threshold concept will stop the progression of learning. The threshold concept framework addresses the kind of complicated learner transitions learners undergo (Cousin, 2008). Recognising threshold concepts and the different ways individual learners approach them will enable educators to make the curriculum more effective and efficient and to unlock learner progress.

The significance of the framework provided by threshold concepts lies, we feel, in its explanatory potential to locate troublesome aspects of disciplinary knowledge within transitions across conceptual thresholds, and hence to assist teachers in identifying appropriate ways of modifying or redesigning curricula to enable their students to negotiate such transitions more successfully. (Land, Cousin, Meyer, \& Davies, 2006, p. 205)

Osmond et al. (2008, p. 244) used the threshold concept framework as lens to identify the "underlying agenda of things students need to have" in the context of a transport and product design course. By clarifying the "knowledge practices" (p. 244) students needed to acquire, Osmond et al. (2008) sought to identify pedagogic strategies to enhance the student learning experience. This potential benefit is of particular interest in entrepreneurship, which has not evolved from an academic context, but is a product of the market. The threshold concept framework offers a way of seeing and understanding disciplinary ways of thinking (Donald, 2002) and 'ways of thinking and practising' (McCune \& Hounsell, 2005) in the discipline. An understanding of the threshold concepts of a discipline supports a person in becoming part of the 'disciplinary tribe' (Becher \& Trowler, 2001) and helps reveal a discipline's underlying episteme (Timmermans \& Meyer, 2017).

\section{The Six Candidate Threshold Concepts in Entrepreneurship}

A staged stakeholder curriculum inquiry involving semi-structured interviews, a Delphi survey and concept mapping workshops was conducted with entrepreneurs, entrepreneurship educators and entrepreneurship students in a doctoral research study (Hatt, 2020). 
Six CTCs in entrepreneurship were developed from the combined entrepreneur and entrepreneurship educator data sets. These CTCs can be used to explain what is distinctive about thinking like an entrepreneur and offer a complementary conceptual grounding to identify what is distinctive about entrepreneurship to enable curricular development and the integration of entrepreneurship with diverse academic subjects beyond business.

\section{Entrepreneurial Agency}

The entrepreneur practises value creation as a self-organising, proactive and self-regulating individual who reflects on and learns from their behaviour in order to contribute to their life circumstances.

\section{Context Is Opportunity}

The entrepreneur realises that all contexts can be contexts for value creation, and as such are rich in opportunity, even those that others might not regard as such.

\section{Context Is Resource}

The entrepreneur realises that all contexts present the means to enable value creation through the exploitation of the opportunities that have been or are yet to be recognised. All contexts not only are the source of opportunity for the creation of value but also present the means with which to bring it to fruition.

\section{Risk Is Missed Opportunity}

The entrepreneur associates risk with opportunities for value creation that are not pursued as well as those that are, in terms of opportunity cost. Risk is more likely to be associated with actions not taken, rather than actions taken. There is a bias towards action and away from caution and inaction. Negative consequences are perceived to be more likely associated with actions not taken, rather than with actions taken.

\section{Value Is Determined by the Customer}

The entrepreneur understands the subjective nature of value creation and recognises that only the prospective customer may perceive value. The customer plays a superordinate role in valuing the offer, and the entrepreneur relegates their own perceptions of value. 


\section{Entrepreneurship Is a Practice}

The entrepreneur practices value creation iteratively and not as a singular event. Value creation is not a 'one off' and entrepreneurs are always thinking of the next opportunity.

\section{How to Educate Students in Entrepreneurship}

Having identified the CTCs in entrepreneurship above, the pedagogical design must also be taken into consideration. Operating best within a framework for engagement, a pedagogical approach was developed from educator data, to create both a desire and an enabling context for experiential entrepreneurship education. Students need to understand the relevance of the knowledge to them and why and when it could prove useful.

Integrated experiential learning opportunities are important, and practical, real-life activities need to form significant parts of the curriculum. Time for reflection needs to be designed in and students need to be given the opportunity to understand failure as a valuable learning experience, although this is particularly challenging in an educational context with an increasingly diverse student cohort. Theoretical knowledge content needs to be integrated with practical experiences and teamwork was critical in encouraging students to develop independence from tutors. Teams can be used as a resource for both knowledge and emotional support and can be pivotal in the development of student engagement, and improved student outcomes. Teaching entrepreneurship knowledge content is important, supporting the argument that theory is the most practical thing that students can be taught (Kuhn, 1962). Use of theory ensures that students are able to act when they encounter new or unfamiliar situations.

The case studies in this chapter illustrate aspects of the pedagogical design of the UK Team Academy style programmes and associate the development of understanding of some of the CTCs in entrepreneurship with them. 


\section{Conclusion}

This chapter sets out some of the challenges in enterprise and entrepreneurship education, presenting the Team Academy approach as a partial answer. Candidate threshold concepts are offered as way to address the lack of conceptual entrepreneurship knowledge taught in the current form of such programmes. If entrepreneurship is regarded not only as an instrumental good (valuable because of what it enables students to do) but also as an intrinsic good (valuable as an end in itself), a more conceptual approach is called for.

Education, according to Collini (2012), encourages students to recognise the ways in which particular bits of knowledge are not fixed, eternal, universal or self-sufficient, by exposing them to the experience of enquiry into those things. Almost any subject matter may be the subject of such enquiry, but there has to be engagement with a 'particular' subject matter. It cannot be done by ingesting a set of abstract propositions about the contingency of knowledge.

Establishing a clearer subject identity for entrepreneurship using threshold concepts allows it to defend itself from the perils of genericism. As it is a product of the market, entrepreneurship shares a kind of emptiness with generic skill sets, which can be explained by its previous lack of intrinsic theoretical and conceptual content. Collini (2012) argues that generic skills are effectively becoming abstract propositions when incorporated into the curriculum without the requirement of the students to engage in a particular subject matter. The skills agenda is "rather like training people in tricks for improving their memory but without their having any past to recall" (Collini, 2012, p. 145).

A well-functioning university delivers many positive indirect outcomes resulting from the primary outcomes of education, advanced scholarship and research. In as much as the purpose of a university course in entrepreneurship may be regarded as the 'means', the direct outcomes may be regarded as the 'ends'. There are many other indirect outcomes of a university, but they should not be confused with its overarching purpose. The reason for the existence of a university is not to produce the indirect outcomes it does. A course in entrepreneurship does not exist in order to 
maximise the employability of its graduates or to generate student startup businesses although again these outcomes might well result as indirect by-products. Likewise, in the course of furthering advanced scholarship and research it is likely that graduates will be well prepared for the future, being highly employable and possibly starting their own businesses thus making a valuable contribution to economic growth.

We constantly fall into the trap of justifying an activity—one initially (and perhaps for long thereafter) undertaken because of its intrinsic interest and worth-as something we do because it yields incidental benefits which are popular with those not in a position to appreciate the activity's intrinsic interest and worth. If we find ourselves saying that what is valuable about learning to play the violin is that it helps develop the manual dexterity that will be useful for typing, then we are stuck in a traffic-jam of carts in front of horses. (Collini, 2012, p. 91)

Four case studies follow this chapter, each illustrating an aspect of the Team Academy approach to entrepreneurship education in more detail and drawing out how each attempts to teach 'about', 'through' and 'for' entrepreneurship, linking to specific CTCs in entrepreneurship.

\section{Case Study 1}

Letting Students Learn by Creating Value for a Third Party (Lucy Hatt, in a previous role of Senior Lecturer, Northumbria University, Newcastle, UK)

'Effective Team Working' is a level four (first year) module running as part of the Team Academy style programme at Northumbria University. It was informed by the work of Lackéus (2015b) who suggests value creation as an educational philosophy. This can be summarised as letting students learn by applying their competencies to create something of value for an external stakeholder. In doing this, the entrepreneurial competencies of self-efficacy, tolerance of uncertainty and ambiguity, and interpersonal skills are developed. These competencies are also highly attractive to employers. Lackéus found strong links between interacting with the outside world and the development of entrepreneurial 
self-efficacy. Hence this assignment requires students to deliver a workshop to pupils in their old school or college around the topic of effective team working in an enterprising context, of their own design. The task develops an increased tolerance for uncertainty and ambiguity, as arrangements and rearrangements have to be made and the schools' or colleges' needs identified and met. By completing this task in teams, interpersonal skills are developed along with greater levels of self-awareness. This task not only develops the enterprising skills of both the university students and the pupils of the schools and colleges they visit, but also promotes the university, the programme and the experiential learning approach to our target audience, driving recruitment. Summative assessment is in the form of an individual reflective report on the experience of undertaking this challenge.

The course requirement for students to start their own business means that the restrictions on visas for international students prevent them from taking it. The timing of the assessments is fixed to allow for students to deliver the workshops from their home addresses if necessary. The team approach permits students who are unable to return to their own school or college for whatever reason to join with others who are.

The successful completion of this assignment builds an understanding in the students of two of the candidate threshold concepts in entrepreneurship set out in the preceding chapter: entrepreneurial agency and value is determined by the customer.

The task at first appears to be very challenging; however, the risk exposure and perceived vulnerability of individuals is limited by team membership. The students usually form a very robust support network for each other. The students are required to regulate and organise themselves into teams and to be proactive in approaching the schools and colleges. They are also required to gather feedback from their team members and the workshop participants and reflect on it, in order to fully realise their learning from the experience and be able to apply it in other circumstances. This experience allows them to develop a greater understanding of entrepreneurial agency.

As the value created in the form of the workshop is authentic, and the workshops are not artefacts created solely for the purposes of assessment, 
the task is meaningful and motivates the students to deliver their best work. As the 'customers' or workshop participants are real, and give real feedback, it is their perspective that has the greatest weight in the perception of the value of what the students have created. This experience allows them to develop a greater understanding of value is determined by the customer.

Several students stated in their assignments that this task had been one of the most valuable on the programme. One student noted:

In terms of my personal growth and the bond I have created with my team, I feel that this workshop has been far more influential than any of the other tasks I have been part of this year. ... the whole assignment was down to the team and myself, and what effort we put in we would get out. For example, we had to find somewhere to conduct the workshop, arrange what we wanted to do and I believe this freedom has increased my commitment for wanting success. I feel the lack of restriction allowed me to use my creative side and explore this when coming up with the workshop. ... this has opened my eyes to a new set of potential skills that I may hold, and I look forward to exploring these in the future.

\section{Case Study 2}

Collaboration Between Students of Law and Entrepreneurship (Lucy Hatt, in a previous role of Senior Lecturer, Northumbria University, Newcastle, UK)

Some of the information in this case study was prepared by Victoria Roper, Senior Lecturer, Northumbria School of Law, Northumbria University, and used with her permission.

An ongoing cross-disciplinary teaching and learning project at Northumbria University involves law students and entrepreneurship students on a Team Academy style programme working collaboratively to share and build upon their knowledge. The law students are participating, as part of their studies, in the Student Law Office in the Faculty of Business and Law at Northumbria University which offers a free legal advice and representation service to the public to those who cannot afford 
it, through clinical practice. Final-year Business Law students and students from the Team Academy style programme work together in teams to help each other identify legal issues and solve business problems. They meet regularly over the course of the academic year. The project was designed with constructivist principles in mind and a philosophy that "teaching is not a matter of transmitting but of engaging students in active learning, building their knowledge in terms of what they already understand" (Biggs \& Tang, 2011, p. 22). Unusually, the project immerses students in the roles of both learner and teacher, whilst exposing them to students from another discipline.

The constructivist ideology underpinning the teaching project suggests students learn best when they are given the opportunity to build their own understanding, knowledge and learning, instead of "acquiring it prepackaged and ready-made" (Exley \& Dennick, 2004, p. 5). The project was designed to bridge the gap between theory and practice through experiential learning. In particular, it allows students to appreciate the complexity of 'real life'.

The business students have no legal background are often ignorant of the legal factors that should be taken into consideration when starting a business. They are commonly faced with legal problems relating to their start-up business projects which they are unsure how to resolve. The law students have been studying law for a number of years and are given the opportunity, through the project, to apply their knowledge to real-life businesses. The project is designed to bridge the gap between theory and practice through experiential learning. In particular, it allows students to appreciate the complexity of 'real life'.

Wider lessons for collaborative learning and teaching more generally have been extrapolated from the project and findings have been used to inform practice in other parts of the Faculty, through a staff development workshop, the university, and the wider higher educational community. The project has general relevance to any disciplines considering working together. The project has also been a transformational experience for staff of two disciplines that, although in the same faculty, are based in different locations and rarely come into contact. The project has made an outstanding contribution to the professional development of colleagues, in 
particular early career teachers, by affording them exposure to experiential teaching with multiple students from different disciplines, in sharp contrast to more traditional didactic approaches where the teacher teaches and the student listens.

The project builds an understanding in the entrepreneurship students of one of the candidate threshold concepts in entrepreneurship set out in the preceding chapter: Context is Resource. Through participating in this project, the students realise that their current educational context presents the means to enable value creation through the exploitation of the opportunities that have been or are yet to be recognised. They learn that they have access to knowledge from multiple sources, including students on other programmes, not just their course lecturers. Students come to understand that all contexts not only are the source of opportunity for the creation of value but also present the means with which to bring it to fruition.

\section{Case Study 3}

A Self-Managed Learning Contract (Lauren Davies, Team Coach/Lecturer in Enterprise and Entrepreneurship, University of the West of England, UK)

A core aspect of the Team Entrepreneurship programme (another example of a Team Academy style programme) at the University of the West of England (UWE Bristol) is self-managed learning. It is argued that the absence of a manager to dictate development goals requires entrepreneurs to develop a high level of self-awareness to set their own goals and measure progress towards them. Irrespective of whether students go on to run their own venture after graduating, developing skills in self-reflection and the ability to manage one's own learning and development can be considered core enterprising competencies and thus attractive to a wide range of employers, as well as being key for those pursuing entrepreneurial career paths. The QAA, 2018 Guidance in Enterprise and Entrepreneurship Education, for instance, lists 'action and reflection' as a core entrepreneurial competency for entrepreneurs and intrapreneurs alike. It is argued that "individuals successful in 
enterprise or entrepreneurship often have heightened levels of self-awareness developed through reflecting upon, and continually learning from, their actions; they use failure to inform progress" (QAA, 2018, p. 24).

The ability to manage one's own learning through critical self-reflection is considered a core entrepreneurial competency. However, since working effectively in a team is a core component of the programme, students also need to develop the ability to agree their individual development goals with their team company. This mirrors the reality of professional development within organisations in which personal goals must align to organisational goals. Furthermore, by agreeing personal goals with their team members, students learn to hold each other accountable and to develop coaching skills by ensuring their peers have set appropriate goals and are making adequate progress towards them.

This approach is underpinned by the Learning Contract, a written assessment that focuses on self-reflection and the setting and monitoring of personal development goals. The Learning Contract is created by all students on the programme at the start of each academic year and reviewed at regular intervals throughout the year. The Learning Contract seeks to answer the following key questions:

- Where have I been?

- Where am I now?

- Where do I want to get to?

- How will I get there?

- How will I know when I have arrived?

Students draw on reflections of their learning prior to joining Team Entrepreneurship and/or from the past year(s) on the programme to further understand their strengths, development areas, interests and motivations and utilise these insights to establish clear goals for the year ahead. The Learning Contract is reviewed and agreed by their team members, and to achieve good marks they should reflect upon the feedback they have received from peers and how this has informed the development of their Learning Contract.

Students update their Learning Contract on a regular basis, discussing changes and updates with their Team Company and writing blog posts to 
summarise key updates and progress. They then submit a final Learning Contract towards the end of the academic year in which they reflect on their progress towards the goals established at the start of the year and discuss whether their goals have changed and what they have learned about themselves over the past academic year. The Learning Contract is marked by the student's Team Coach who provides feedback on the appropriateness of their goals, plans and commitments and on the effectiveness of their self-reflection and insights gained from team feedback. While the Learning Contract is marked by the Team Coach, it is the student and their peers that establish and agree their personal development goals, thus offering a high degree of personal autonomy over their learning.

This self-managed, iterative approach to learning aligns with the recommendation of Robinson, Neergaard, Tanggaard, and Krueger (2016) for a need to move away from teacher-led entrepreneurship education to more student-centred learning and a focus on lifelong learning practices. By allowing students to set their own goals and take responsibility for monitoring their progress against them, a greater sense of personal ownership is achieved amongst the cohort. This approach encapsulates the CTC of entrepreneurial agency discussed earlier in this chapter in which entrepreneurs are viewed as self-organising, proactive, self-regulating individuals with the ability to reflect on and learn from their current and past experiences.

In summary, the Learning Contract encapsulates the self-managed approach to learning that is core to Team Academy and utilises an iterative, self-reflective assessment to facilitate students' approach to managing their own learning. The process of reviewing and agreeing their Learning Contract with their Team Company provides students with experience of giving and receiving constructive feedback, and they are assessed on how effectively they reflect on and utilise this feedback. The Learning Contract draws together key learnings from the students' entrepreneurial practices as well as their reflections on their individual goals, strengths, development areas and motivations, thus enabling them to develop high levels of self-awareness and strengths in critical self-reflection. 


\section{Case Study 4}

The Client Project (Lauren Davies, Team Coach/Lecturer in Enterprise and Entrepreneurship, University of the West of England, UK)

The Client Project is a practical, team-based assignment that runs in parallel across all three-year groups within the Team Entrepreneurship programme at the University of the West of England (UWE Bristol). Students work in teams comprised of a sub-group of members within their Team Company and sub-groups of members from Team Companies in the other year groups. This is a fairly unique example of students working collaboratively on an assessment across different levels of study, and this innovative approach helps to build a strong sense of cohort identity.

The approach also requires students to adopt specific roles, with finalyear students acting as consultants to the second-year students, secondyear students taking on a team leadership role and first-year students executing the project under the guidance of their second-year team leaders. This allows students to develop different roles over the course of the programme and to draw on their experiences from the previous year. The second-year students can learn a lot about effective team leadership skills from reflecting on those that were (or were not) demonstrated by their team leaders the previous year.

The Client Project exemplifies the CTC of value is determined by the customer as described previously in this chapter. Students are required to complete a specific project for an external client and to produce a report and presentation outlining the work they have completed and their recommendations for the future growth and development of the external organisation. The brief is outlined by the client, and they are assessed by how effectively they have met the brief with the client's feedback on their report and presentation informing their final grade for the assessment. This requires students to listen and understand the needs of their client and to ensure that they are delivering value as defined by the external organisation. Students must also consider the value that they bring to the project as defined by their other team members, since they are assessed for their individual contribution by their peers with the option to deduct or increase individual marks according to each team member's contribution. 
The Client Project also provides opportunity for students to build connections with external stakeholders and to develop experience of working in a business-to-business environment. For students with smaller-scale business-to-consumer ventures or those that have experienced difficulty in establishing a new venture, the Client Project can provide a transformative learning experience. Within the National Student Survey students have described it as "the best experience that I use for interview examples" and regarded it as a "fantastic opportunity" for solving real problems for real businesses.

For some students the client project has helped to achieve the CTC of context is opportunity, as described previously in this chapter. Those that have maximised the opportunity of the Client Project have realised that it offers much greater value than simply achieving a good grade in the assessment, providing opportunity for meaningful connections to be established with external organisations that can lead to further opportunities. For example, a final-year student that took part in the Client Project in his second year has continued to work with his client on a consultancy basis. In their final year of study on Team Entrepreneurship students at UWE Bristol have four options for their final-year Creative Enquiry Project (equivalent to a dissertation on a more traditional programme). One of the options is a consultancy project for an external client, and this student has taken this option, continuing to create and gain value from the client relationship established during his second year.

Reflecting on his experience of working with the client, this final-year student said:

The first time I came into contact with (the client) was January 2019, in my second year of Team Entrepreneurship at UWE whilst undertaking the mandatory marked client project. They had recently created a business that sells a small, rocket-shaped accessory that is sold internationally. They gave us a challenging six-part assignment, including a big competitor analysis task, research into their international distributors and developing some tools for them to use to contact their distributors. We managed to carry out the assignment to a high standard, got great feedback from the clients and achieved a high 2:1 for the assignment. Fast forward a year, and I am currently working with them again as part of a consultancy style dissertation. 
I currently act for them as a marketing strategy consultant, carrying out an audit on their digital marketing presence and recommending changes to their digital marketing strategy.

The Client Project is also a prime example of the UWE Bristol Team Entrepreneurship approach to curriculum design which mirrors the iterative nature of entrepreneurial practice that is expected of students. The programme team utilises feedback from students to make changes to modules and assessments each year, thus building on learnings from previous years and ensuring that student feedback is acted upon where applicable. Based on feedback from last year's students regarding low levels of engagement from final-year students, the programme team has made a key change to the client project for 2019-2020. Previously, the clients were selected for the students using the contacts of the Team Coaches and wider programme team. In some instances, this resulted in final-year students having little understanding of the needs of the clients and thus limited scope to offer effective consultancy to their second-year sub-team. It also meant the students were less invested in the project overall since the clients were selected for them. To overcome these issues for 2019-2020 the programme team have introduced a new aspect to the Client Project in which the final-year students have to source the clients for their second-and first-year teams. The impact of this change is explained further by another final-year student:

Last year the clients were given to us, and the final-year students didn't really know much about the clients so they couldn't really help us as secondyear students to help the client. This shows that if you are given something and you didn't put any effort into it, you will be less motivated and will not understand how best to complete the task. However, this year we have the opportunity to get to know the clients by sourcing them ourselves, and we will be of greater support to our second-year teams as we will understand the problems the client has.

The student also discussed the skills he is developing through having to source clients directly, including the confidence and ability to speak to potential clients over the phone, adapting the message each time and learning from each failure and success. 
In summary, the Client Project is an innovative example of experiential learning via a live project. The project requires a strong understanding of value is determined by the customer, as well as by peers. The project offers a unique opportunity for students to collaborate across the three levels of study and utilise insights gained from previous engagements in the project to inform their approach as their roles adapt at each level. The newly added component of final-year students sourcing clients adds a new dimension to the project with final-year students displaying greater levels of commitment and motivation and developing key skills in communicating effectively with external stakeholders.

\section{References}

Akatemia - working to learn. (2019). Retrieved from http://www.akatemia.org.uk/

Barradell, S. (2013). The identification of threshold concepts: A review of theoretical complexities and methodological challenges. Higher Education, 65(2), 265-276.

Barradell, S., \& Kennedy-Jones, M. (2015). Threshold concepts, student learning and curriculum: Making connections between theory and practice. Innovations in Education and Teaching International, 52(5), 536-545. https:// doi.org/10.1007/s10734-012-9542-3

Béchard, J.-P., \& Grégoire, D. (2007). Archetypes of pedagogical innovation for entrepreneurship in higher education: Model and illustrations. In Handbook of research in entrepreneurship education: A general perspective (Vol. 1, pp. 261-284). Cheltenham \& Northampton, MA: Edward Elgar.

Becher, T., \& Trowler, P. R. (2001). Academic tribes and territories: Intellectual enquiry and the cultures of disciplines (2nd ed.). Buckingham: SRHE/ Open University Press.

Biggs, J. B., \& Tang, C. (2011). Teaching for quality learning at university: What the student does (4th ed.). Maidenhead: McGraw-Hill Education (UK).

Collini, S. (2012). What are Universities for? London: Penguin Books Ltd..

Cousin, G. (2008). Old wine in new bottles or a new form of transactional curriculum inquiry? In R. Land, J. Meyer, \& J. Smith (Eds.), Threshold concepts within the disciplines (pp. 261-272). Rotterdam: Sense Publishers.

Cousin, G. (2009). Researching learning in higher education. New York: Routledge. 
Davey, T. (2016). Team learning through starting a business at Tiimiakatemia. Retrieved from University-Business Cooperation in Europe website: https:// ub-cooperation.eu/index/casestudies

Davey, T. (2018, February 26). TIIMIAKATEMIA Finland (TEAM ACADEMY) - Earn A Degree By Building A Successful Business! - UIIN Blog. Retrieved from https://blog.uiin.org/2018/02/ tiimiakatemia-finland-team-academy-earn-degree-building-successful-business/

Davey, T., Hannon, P., \& Penaluna, A. (2016). Entrepreneurship education and the role of universities in entrepreneurship: Introduction to the special issue. London, England: SAGE Publications.

Donald, J. G. (2002). Learning to think: Disciplinary perspectives. The Jossey-Bass Higher and Adult Education Series: ERIC.

Entrepreneurship Policy Framework and Implementation Guidance. (2012). Retrieved from New York and Geneva: http://unctad.org/en/ PublicationsLibrary/diaeed2012d1_en.pdf

Exley, K., \& Dennick, R. (2004). Small group teaching: Tutorials, seminars and beyond. London: RoutledgeFalmer.

Fiet, J. O. (2001). The theoretical side of teaching entrepreneurship. Journal of Business Venturing, 16(1), 1-24. https://doi.org/10.1016/ S0883-9026(99)00041-5

Gibb, A. (2002). In pursuit of a new 'enterprise' and 'entrepreneurship' paradigm for learning: Creative destruction, new values, new ways of doing things and new combinations of knowledge. International Journal of Management Reviews, 4(3), 233-269. https://doi.org/10.1111/1468-2370.00086

Halttunen, J. (Producer). (2006, 28/01/2019). Team Academy - Award winning entrepreneurship education from Jyvaskyla, Finland. Presentation given at OECD/IMHE Conference, Copenhagen, Denmark.

Hannon, P. (2005). Philosophies of enterprise and entrepreneurship education and challenges for higher education in the UK. Entrepreneurship and Innovation, 6(2), 105-114. https://doi.org/10.5367/0000000053966876

Hatt, L. (2020). Using the threshold concept framework to enhance entrepreneurship curricula in higher education. (PhD), University of Durham, Durham.

Heinonen, J., \& Hytti, U. (2010). Back to basics: The role of teaching in developing the entrepreneurial university. The International Journal of Entrepreneurship and Innovation, 11(4), 283-292.

Helping entrepreneurs flourish: Rethinking the drivers of entrepreneurship. (2014). The Economist Intelligence Unit Retrieved from https://perspectives.eiu.com/talent-education/helping-entrepreneurs-flourish/white-paper/ helping-entrepreneurs-flourish?redirect=TRUE 
Hofer, A., Potter, J., Fayolle, A., Gulbrandsen, M., Hannon, P., Harding, R., ... Phan, P. H. (2010). From strategy to practice in university entrepreneurship support.

Kirschner, P. A., Sweller, J., \& Clark, R. E. (2006). Why minimal guidance during instruction does not work: An analysis of the failure of constructivist, discovery, problem-based, experiential, and inquiry-based teaching. Educational Psychologist, 41(2), 75-86. https://doi.org/10.1207/ s15326985ep4102_1

Kuhn, T. S. (1962). The structure of scientific revolutions (2nd ed.). Chicago, IL: University of Chicago Press.

Lackéus, M. (2015a). Entrepreneurship in education: What why, when how. Entrepreneurship360 background paper. Paris: OECD. Retrieved from https://www.oecd.org/cfe/leed/BGP_Entrepreneurship-in-Education.pdf Lackéus, M. (2015b). Value creation as educational philosophy. (Doctor of Engineering). Gothenburg, Sweden: Chalmers University of Technology.

Land, R., Cousin, G., Meyer, J. H. F., \& Davies, P. (2006). Conclusion: Implications of threshold concepts for course design and evaluation. In J. Meyer \& R. Land (Eds.), Overcoming barriers to student understanding: Threshold concepts and troublesome knowledge (pp. 195-206). London, New York: Routledge.

Leinonen, N., Partanen, J., \& Palviainen, P. (2004). The team academy: A true story of a community that learns by doing. Jyväskylä: PS-kustannus.

Lizartza, A. (2012). Introducing Team Academy Finland. Retrieved from https:// www.slideshare.net/alizartza/introducing-team-academy-finland

Matlay, H., \& Carey, C. (2007). Entrepreneurship education in the UK: A longitudinal perspective. Journal of Small Business and Enterprise Development, 14(2), 252-263.

McCune, V., \& Hounsell, D. (2005). The development of students' ways of thinking and practising in three final-year biology courses. Higher Education, 49(3), 255-289. https://doi.org/10.1007/s10734-004-6666-0

Meyer, J. H. F., \& Land, R. (2003). Threshold concepts and troublesome knowledge (1) linkages to ways of thinking and practising within the disciplines. In Improving student learning theory and practice - 10 years on (pp. 412-424). Oxford: OCSLD.

Meyer, J. H. F., \& Land, R. (2005). Threshold concepts and troublesome knowledge (2): Epistemological considerations and a conceptual framework for teaching and learning. Higher Education, 49(3), 373-388. https://doi. org/10.1007/s10734-004-6779-5 
Michels, N., Beresford, R., Beresford, K., \& Handley, K. (2018). From fluctuation and fragility to innovation and sustainability: The role of a member network in UK enterprise education. Industry and Higher Education, $32(6), 438-450$.

Morselli, D. (2019). The assessment of entrepreneurial education. In The Change Laboratory for Teacher Training in Entrepreneurship Education (pp. 17-36). London: Springer.

Neck, H. M., \& Corbett, A. C. (2018). The scholarship of teaching and learning entrepreneurship. Entrepreneurship Education and Pedagogy, 1(1), 8-41. https://doi.org/10.1177/2515127417737286

Nielsen, S. L., Klyver, K., Evald, M. R., \& Bager, T. (2012). Entrepreneurship in theory and practice: Paradoxes in Play. Cheltenham: Edward Elgar Publishing.

O'Connor, A. (2013). A conceptual framework for entrepreneurship education policy: Meeting government and economic purposes. Journal of Business Venturing, 28(4), 546-563. https://doi.org/10.1016/j.jbusvent.2012.07.003

Osmond, J., Turner, A., \& Land, R. (2008). Threshold Concepts and spatial awareness in transport and product design. In R. Land, J. Meyer, \& J. Smith (Eds.), Threshold Concepts within the disciplines (pp. 243-258). Rotterdam: Sense Publishers.

Pittaway, L., \& Cope, J. (2007). Entrepreneurship education: A systematic review of the evidence. International Small Business Journal, 25(5), 479-510.

Pittaway, L., \& Edwards, C. (2012). Assessment: Examining practice in entrepreneurship education. Education + Training, 54, 778-800.

QAA. (2012). Enterprise and Entrepreneurship Education. Guidance for UK Higher Education Providers. Retrieved from http://www.qaa.ac.uk/docs/qaas/ enhancement-and-development/enterprise-and-entrepreneurship-education-2018.pdf?sfvrsn=15f1f981_8

QAA. (2018). Enterprise and Entrepreneurship Education: Guidance for UK Higher Education Providers. Retrieved from https://www.qaa.ac.uk/docs/ qaas/enhancement-and-development/enterprise-and-entrpreneurship-education-2018.pdf?sfvrsn=15f1f981_8

Robinson, S., Neergaard, H., Tanggaard, L., \& Krueger, N. F. (2016). New horizons in entrepreneurship education: From teacher-led to studentcentered learning. Education + Training, 58(7/8), 661-683.

Rothblatt, S. (2006). The modern university and its discontents: The fate of Newman's legacies in Britain and America. Cambridge: Cambridge University Press. 
Ruuska, J., \& Krawczyk, P. (2013). Team academy as learning living lab. Paper presented at the European Phenomena of Entrepreneurship Education and Development. University Industry Conference, Amsterdam.

Shanahan, M., Foster, G., \& Meyer, J. H. F. (2008). Associations among prior acquisition of Threshold Concepts, learning dimensions, and examination performance in first year economics. In R. Land, J. H. F. Meyer, \& J. Smith (Eds.), Threshold Concepts within the disciplines (pp. 155-172). Rotterdam: Sense Publishers.

Team Academy Worldwide. (n.d.). Retrieved from www.akatemia.org.uk/whatis-team-academy/team-academy-worldwide/

Timmermans, J. A., \& Meyer, J. H. F. (2017). A framework for working with university teachers to create and embed 'Integrated Threshold Concept Knowledge' (ITCK) in their practice. International Journal for Academic Development, 20, 1-15. https://doi.org/10.1080/1360144X.2017.1388241

Tosey, P., Dhaliwal, S., \& Hassinen, J. (2015). The finnish team academy model: Implications for management education. Management Learning, 46(2), 175-194. https://doi.org/10.1177/1350507613498334

Zander, C., Boustedt, J., Eckerdal, A., McCartney, R., Moström, J. E., Ratcliffe, M., \& Sanders, K. (2008). Threshold concepts in computer science: A multinational empirical investigation. In Threshold concepts within the disciplines (pp. 105-118). Leiden: Brill Sense.

Open Access This chapter is licensed under the terms of the Creative Commons Attribution 4.0 International License (http://creativecommons.org/licenses/ by/4.0/), which permits use, sharing, adaptation, distribution and reproduction in any medium or format, as long as you give appropriate credit to the original author(s) and the source, provide a link to the Creative Commons licence and indicate if changes were made.

The images or other third party material in this chapter are included in the chapter's Creative Commons licence, unless indicated otherwise in a credit line to the material. If material is not included in the chapter's Creative Commons licence and your intended use is not permitted by statutory regulation or exceeds the permitted use, you will need to obtain permission directly from the copyright holder. 